ELORE (ISSN 1456-3010), vol. $12-1 / 2005$.

Julkaisija: Suomen Kansantietouden Tutkijain seura ry.

Toimittaneet: Outi Fingerroos ja Kaarina Koski. Taitto: Jukka Talve.

[http://cc.joensuu.fi/ loristi/1_05/fin_b_1_05.pdf]

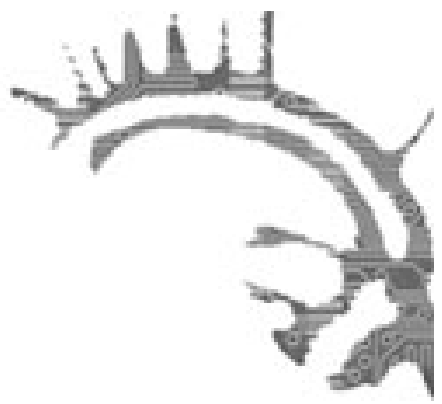

\title{
"Kuulaa Kalloon"
}

Toivo Kuulan kuolema Viipurissa

\section{Outi Fingerroos}

Suomen sisällissota päättyi huhtikuussa 1918. Karjalankannaksesta tuli sodan loppuvaiheessa punaisen sodankäynnin keskus, sillä kansanvaltuuskunnan tärkeimmät henkilöt siirtyivät Helsingistä Viipuriin 9. huhtikuuta. Viipurissa ei enää nähty toimintakykyistä kansanvaltuuskuntaa, sillä moni sen jäsenistä jatkoi matkaansa Venäjälle. Viipurin kaupunkia suojaavat rintamalinjat murtuivatkin pian johdon paon jälkeen huhtikuun 28.-29. päivinä. (Fingerroos 2004, 299-301; Lappalainen 1981, 218; Soikkanen 1970, 241-250, 313-315, 281; myös Rinta-Tassi 1986, 465-474.)

Sisällissodan liepeillä ilmeni monenlaisia, ihmisyyden kannalta ei-toivottuja ilmiöitä. Viipurissa leimallista oli väkivalta, terroriteot ja voiton juhlinta runsas alkoholi kyytipoikana. Viipurin lääninvankilassa 27. huhtikuuta 1918 tapahtunutta joukkomurhaa pidetään yhtenä punaisen terrorin pahimmista. Murhat teki joukko lappeenrantalaisia ja taipalsaarelaisia punakaartilaisia, jotka saapuivat Lappeenrannasta Viipurin lääninvankilaan ja ryhtyivät humalapäissään pitämään tutkintoa. (Eerola \& Eerola 1998, 67, 69; Fingerroos 2004, 301-305; Paavolainen 1967, 162-164; Upton 1981, 191.) Myös valkoisten vallanotto tapahtui väkivaltaisissa ja viinanhöyryisissä merkeissä. Jaakko Paavolainen (1967, 269-270) on arvioinut, että Viipurin ja Tampereen suurten valloitusvoittojen jälkeen joukot rivimiehistä upseereihin saakka nauttivat siinä määrin alkoholia, että voidaan puhua jopa yleisestä juopumuksesta.

Vapunpäivä 1918 ei valjennutkaan Viipurissa kaikkien näkökulmasta kirkkaana. Linnan tornissa liehui valkoinen lippu. Tunnelmia luonnehti selkeä poliittissosiaalinen kaksijakoisuus eli käsitys valkoisista yhteiskunnan rakentavina voimina ja punaisista päinvastaisina, hajottavina aineksina. Mielipiderintama edusti äärimmäisyysajattelua, joka ei sallinut kompromisseja. Epäoikeudenmukaisille kuolemillekin esitettiin moraalinen puolustus, sillä kyseessä oli suomalaisen kansakunnan tulevaisuus. (Ks. Fingerroos 2004, 305-306; Paasivirta 1957, 230-231, 294-295.) 


\section{OUtI FingerRoos}

\section{JOHDANTO}

Tässä artikkelissa liikutaan Viipurin valloitusta seuranneessa valkoisessa juhlahumussa. Paikkana on Viipurin Seurahuone, jossa tapahtui vapunaattona 1918 valkoisen jääkärin tekemä ja paljon epäselvyyttä aiheuttanut ampumavälikohtaus. Uhrina oli eteläpohjalaiseen kansanmusiikkiin perehtynyt säveltäjä Toivo Timoteus Kuula (1883-1918), joka oli viettämässä voitonjuhlia Vaasan rykmentin II pataljoonan jääkäreiden kutsumana vieraana. Viipuriin Vaasassa syntyneen lestadiolaisperheen esikoisen oli tuonut työ: hän toimi Viipurin Musiikinystävien orkesterin kapellimestarina vuodet 1916-1918. Vuoden 1918 kuolema korjasi satonaan myös säveltäjän, joka kuului sekä valkoisten, suomenkielisten ja -mielisten että pohjalaisen kansan riveihin.

Artikkelin tehtävänä on selvittää, millainen muisto säveltäjä Toivo Kuulan kuolemasta jäi elämään ja mitä vastaavasti jätettiin kertomatta. Muistitieto toimii tekstissä lähteenä - ja myös jälkinä ja johtolankoina - selvitettäessä, millaisia totuuksia murhamysteeriosta on muistelutyössä jälkeenpäin esitetty. Tietoteoreettinen lähtökohta on sikäli realistinen, että Toivo Kuulan murhan ympärille kietoutunutta muistia puretaan kerroksittain, jolloin jäljelle jää vaiettu totuus: se, mitä siitä voidaan yli 80 vuotta jälkeenpäin esittää. Artikkeli ei kuitenkaan edusta realistista tai selittävää muistitietohistoriaa, sillä pyrkimyksenä ei ole todellisuuden konstruointi vaan muistin sisältämien merkitysten tasolla tehtävä tulkinta (ks. Portelli 2002, 63-74). Muistin merkitykset ovat itsessään totuuksia, joita ei osoiteta vääräksi - vaikka erilaisten totuuksien olemassaolo todennetaankin - vaan niistä rakennetaan tulkinnassa analogioita ja rekostruktioita. Erityisesti analyysissa korostetaan niitä muistin jälkiä, joista löytyy yhtymäkohtia kansakunnan harjoittamaan muistin politiikkaan. Nämä lähtökohdat huomioiden artikkelin epistemologinen pohja on hyvinkin hermeneuttinen ja analyysi tulkitsevaa, osin krïttisestikin orientoitunutta muistitietohistoriaa. (1)

Kuuluisan säveltäjän poikkeuksellinen kuolema tapahtui valkoisessa Suomessa ja surmanluodin ampui humalainen jääkäri eli oma mies. Valkoinen humala on vaikuttanut paljon julkisen muistelutyön muotoihin. Kïnnostavaksi tapauksen tekee myös se, että ampumiseen johtaneista syistä on olemassa sekavaa todistusaineistoa, mistä syystä kuva kokonaisuudesta on jäänyt epäselväksi. Itse ampumisesta sen sijaan on olemassa silminnäkijätodistuksia. (Paavolainen 1967, 271-272, 422-425.) Seurahuoneen tapahtumat ja keskeneräiseksi jäänyt oikeudenkäynti ovatkin kiehtoneet vuosikymmeniä ihmisten mielikuvitusta ja tuottaneet säännöllisin väliajoin sekä huhuja että asiaa sivuavaa lehtikirjoittelua (ks. Elmgren-Heinonen 1983, 370). Rouva Alma Kuulan elokuussa 1918 kirjoittama päiväkirjaote, jossa hän tilittää tuntojaan miehensä kuoleman jälkeen, on tapahtumiin liittyvän vaitonaisuuden kannalta kuvaava. Rouva Kuula oli ampumisen hetkellä kortteerissa pankinjohtaja Arvo Lintulahden kotona (Elmgren-Heinonen 1953, 426), joten hän eli epävarmuudessa koko yön sekä yötä seuranneet päivät, viikot ja vuodet: 


\section{"KuULAA KALLOON"}

Miten huntava vääryys on se, ettei Toivon asiaa ole vielä saatu selville, eikë murhaajat ansaittua rangaistusta saaneet. Nyt voivat he kulkea vaan kunniaa saaden vapaalla jalalla, ja Toivo on kärsinyt kuoleman heidän takiaan. Minä en ymmärrä nykyisiä lakeja ja nykyistäybteiskuntajärjestystä. Miten se sallii tällaisen asian olla hämäryydessä. Kun H:linnassa eräs upseeri ampui punakaartilaisvangin ilman tutkintoa, niin siitä nostettiin (oikein kyllä) sanomalebtijuttu ja syyllinen saa rangaistuksensa, mutta Toivon ampumisesta eivät lehdet biisku mitään. (HYK Coll. 310. 11. Alma Kuulan päiväkirja; myös Suomen Kuvalehti 30.4.1960.)

Artikkelin päälähteinä käytän Toivo Kuulan henkilöarkistoon tallennettuja Alma Kuulan päiväkirjamerkintöjä, sanomalehtikirjoituksia ja muistitietoa. Arkisto sijaitsee Helsingin yliopiston kirjaston käsikirjoituskokoelmissa. Ylipäätään Toivo Kuulan kuoleman ympärillä tehtävä epävirallinen selvitystyö on jatkunut pian 90 vuotta. Säveltäjän puoliso omisti koko elämänsä miehensä muiston ylläpitämiselle ja teosten tunnetuksi tekemiselle. Hän kuoli vuonna 1941 avioitumatta uudelleen. Sittemmin perheen ainoaksi jäänyt lapsi, Sinikka Kuula-Marttinen, julkaisi edesmenneen äitinsä päiväkirjat vuosilta 1901-1919 otsikolla Virta venhettä vie (1968), ja laulajatar Tuomi Elmgren-Heinonen kirjoitti Toivo Kuula elämäkerran (1938). Internetistä löytyy 18. toukokuuta 1948 perustetun Toivo Kuula-seuran kotisivut. Seuran tavoitteena on tehdä tunnetuksi säveltäjän elämäntyötä ja herättää hänen sävellyksiinsä kohdistuvaa mielenkiintoa ja harrastusta niin kotimaassa kuin ulkomaillakin. (Toivo Kuula-seura ry [online], 28.1.2005.) Helsingin Sanomat kirjoitti 30. lokakuuta 2004, miten Toivo ja Alma Kuulasta on avattu laaja verkkosivusto Helsingin yliopiston kirjaston kotisivuilla (ks. www.lib.helsinki.fi/kuula). Edellisten lisäksi Kuulan muiston vaalimistyöhön ja mysteerin selvittämiseen ovat tarttuneet Paavo Haavikko näytelmäkäsikirjoituksella Soitannollinen ilta Viïpurissa (1978) ja Riku Sarkola teoksellaan Toivo Kuulan Matkanpää. Murhenäytelmä Viipurissa 1918 (1960b) - puhumattakaan lehdistöstä, jolle Kuulan kuolema on ollut todellinen runsauden sarvi, vaikka itse kuolintavasta onkin pitkään vaiettu (ks. erityisesti Niiniluoto 1978; Sarkola 1960a).

\section{Poikkeavan Kuoleman teema}

Kuolemaan liittyy aina paljon kulttuurisia käsityksiä, jotka voivat olla sekä yhteisön hyväksymiä että kieltämiä. Näitä käsityksiä ilmaistaan muiden muassa rituaalein ja muistotyössä, joilla on merkitystä sekä eläville että toimien kohteena oleville kuolijoille. Tässä artikkelissa rituaalien keskeisimpänä funktiona pidetään yhteisöllistä jaettavuutta ja julkisuutta. Toisin sanoen oikein suoritettu kuolemanrituaali on vainajan kannalta kunniallinen ja arvokas sekä kuolema julkisesti hyväksytty. Näin ollen avoimuus on merkki kuoleman normaaliudesta. (Ks. tarkemmin Fingerroos 2004.) 


\section{OUtI FingerRoOS}

Tilanne monimutkaistuu, kun kuoleman julkisuus ja arvo kyseenalaistuvat. Kaikista kuolemista ei esimerkiksi avoimesti tiedoteta ja hautajaiset voivat olla hiljaiset, jopa salatut. Kuolema ei siis ole aina ja kaikille yksi ja sama asia. Poikkeavat knolemat ovatkin vaikeasti tulkittavia, sillä niiden yhteydessä toteutettavat rituaaliset toimet eivät suoraan sovi nimittäjän normaali kuolema alle. Merkitykselliseksi tulee itse kuolintapa ja sitä seuraavat, tapauskohtaisesti ratkaistavat ritualisoinnin muodot. Jos kuolintavan julkisuusarvo on poikkeava, myös kuolemien yhteisöllinen käsitteellistäminen ja jälkeenpäin tapahtuva muisteleminen ovat poikkeavia - ainakin ne vaativat tapauskohtaista pohdintaa. (Fingerroos 2004, passim.)

Toivo Kuulan kuolema sijoittuu jonnekin normaalin ja poikkeavan kuoleman välimaastoon. Kuolintapa ei muuttanut Toivo Kuulan arvoa ihmisenä, sillä ampumista ei varsinaisesti kielletty ja kuolemanrituaalit olivat julkisia. Ainoastaan kuolintavasta ei puhuttu julkisuudessa sen oikeilla nimillä. (Ks. Fingerroos 2004, 255, 262). Kuolintapaa seuranneen rituaalisen käsittelyn ja muistotyön kannalta oleellisempaa oli hänen elämänaikaiselle toiminnalleen annettu arvo ja käyttökelpoisuus. Säveltäjämestarin kuolemasta tehtiin pohjalainen ja kansallinen myytti, jonka prosessointi alkoi välittömästi kuoleman jälkeen muiden muassa suomalaisissa sanomalehdissä. Kuula lähti vapunjuhliin eteläpohjalaisten ystäviensä ja maanmiesten kutsumana ja totesi: "siitä pitääkin tulla hauska vappu (Elmgren-Heinonen 1958, 425).” Rituaalisen kuoleman näkökulmasta Kuulan ampuminen olikin poikkeuksellinen ja järjenvastainen tragedia, sillä illan todennäköinen uhri olisi ollut bolševikki tai punainen upseeri eikä jääkäreille osoitetun Jokamies-marssin säveltäjä. Kuolema tapahtui myös poikkeuksellisissa oloissa, sillä kaupungissa vallitsi sekasorto, voittajat viettivät juhlia ja alkoholia virtasi. Lisäksi Kuulan kuolintapa oli väkivaltainen ja kunniaton, vaikka kuoleman jälkeinen surutyö sai paljon julkisuutta ja säveltäjämestarin lyhyeksi jääneestä urasta tehtiin muisto- ja surutyössä loistokas kansallinen kertomus.

Toivo Kuulan poikkeava kuolema on erinomainen esimerkki kuoleman käsittelyn tapauskohtaisuudesta, kun tulkintaa tehdään merkitysten tasolla. Kuolintapa on aina määrittelyn kohteena eivätkä kuolemaa seuraavat rituaalit välttämättä noudata selvää, yleistä tai jaettua kaavaa. Jälkeenpäin tapahtuva muistelu on erityisen herkkää vivahteille ja merkitysten kasautumiselle. Vuonna 1918 Toivo Kuulan poikkeuksellinen kuoleman syystä oli yksinkertaisinta vaieta, sillä sisällissodan jälkiselvittely oli käynnissä ja kaupungin yli kiiri kuularuiskujen ääniä useiden viikkojen ajan. (Tarkemmin Fingerroos 2004, 251-253; myös Kearl 1989, 120-169; Peltonen 2003, 66-72, 87-88, 94; Pentikäinen 1969, 61, 98; Pentikäinen 1990, 88.) Vaikenemisen kautta synnytettiin kuitenkin merkityksiä: vuosikymmenien saatossa Toivo Kuulan muisto myytillistyi ja syntyi mieliä kiehtova viipurilainen murhamysteeri. (2) 
"KUULAA KALLOON"

\section{"VERTA, VERTA, TÄÄLLÄ ON LOUKATTU JÄÄKÄRIÄ"}

Mitä seurahuoneella sitten tapahtui? Miksi pariskunta Kuula lähti Säiniöltä Viipuriin, vaikka heidän oli tarkoitus lähteä perheen kesäpaikkaan Luhankaan. Toivo Kuula oli kotoisin Vaasasta, joten kutsu Vaasan rykmentin II pataljoonan vieraaksi lienee ollut syy sille, että pariskunta valitsi isänmaallisen vappujuhlan kaupungissa. Tämä selitys on löydettävissä myös rouva Alma Kuulan päiväkirjasta, jonne on kirjattu yksityiskohtainen selvitys tapahtumien kulusta aina aamun varhaisesta kahvihetkestä illan eronhetkeen, jolloin tunnelma Seurahuoneella oli tiivistynyt rouvan mielestä aivan liian vaaralliseksi. Aamulla yhdeksän tienoissa "Sinikka pieni jäi Helmin kanssa portille vilkuttamaan kättä", kun pariskunta lähti auton kyyditsemänä Viipuriin:

[S]itten kïdimme halki niiden seutujen, joissa joitakin päiviä sitten oli burjasti tapettu. Tiellä näkyi palaneita taloja, erään punakaartilaisen ruumis ojan reunalla ja kuolleita hevosia vielä. Pian tulimme Waasan rykmentin II:sen pataljoonan esikunnan asunnolle ins. Hartmanin buoneistoon ja söimme siellä aamiaista. Sieltä menimme Toivon kanssa Patomäelle kahville ja katsomaan, ovatko he vielä hengissä. Siellä oli ilo meillä kaikilla suuri. Joukolla lähdimme sitten katsomaan kentälle paraatia kello 2 ja sieltä Seurabuoneelle, jonne meitä oli pyydetty vieraaksi Waasan rykmentin huoneeseen. (HYK Coll. 310. 11. Alma Kuulan päiväkirja.)

Seurahuoneella vallitsi Alma Kuulan kuvauksen perusteella innostunut mieliala. Toivo Kuula soitti ja lauloi harjoitellen säveltämäänsä suojeluskunnan marssia. Lisäksi hän piti jääkäreille ja suojeluskuntalaisille puheita. Säveltäjä oli vaimon mukaan intoa täynnä ja kohotti lopulta eläköön-huudon jääkäreille, suojeluskuntalaisille ja suomalaiselle Suomelle luvaten itse heiluttaa hengen miekkaa innokkaammin kuin koskaan ennen. Laulajatar Kuula esitti miehensä säestyksellä vielä Lauantaiillan ja Syystunnelman, minkä jälkeen he kiertelivät muissa huoneissa. Toivo Kuula "heitti konfetteja joka jääkärin päälle, joka eteen sattui" ja esitteli heille vaimonsa, laulajattaren. Vähän kello yhdeksän jälkeen rouva Kuula kuitenkin rupesi tekemään lähtöä, ja olisi tahtonut miehensäkin mukaan:

Mutta toverit vakunttivat pitävänsä Toivosta buolen ja Toivo taputti minua olkapäälle sanoen: "Tämä minun pik.ku emäntäni on vähän hermostunut. Mene sinä Ammi vaan raubassa nuk.kumaan, kyllä minä tulen kotiin." Luok.katoverinsa Einari Luoman bän lähetti minua saattamaan ajurilla kotiin. Sanoin siis Toivolle byvästit syleillen ja jätin bänet reippaana sinne, aavistamatta mitä oli tapabtuva muntaman hetken kuluttua. (HYK Coll. 310. 11. Alma Kuulan päiväkirja.) 


\section{OUtI FingerRoOS}

"Ammin" (lempinimi) ja muiden naisten lähdettyä juhlinnan vauhti kiihtyi, mikä näkyy myös myöhemmin kirjoitettujen kuvausten vauhdissa ja värikkyydessä (esim. Elmgren-Heinonen 1983; Niiniluoto 1978; Paavolainen 1967; Sarkola 27-35). Erilaisten kuvausten perusteella illan tapahtumista rakentuu pirstaleinen kuva, joka alkaa hahmottua siitä hetkestä, kun erääseen Seurahuoneen kabinettiin tuotiin 25 litran spriikanisteri. Väki oli humalassa ja Toivo Kuula heidän mukanaan. Seurahuoneen sokkeloissa oli ilmeisesti niin paljon väkeä, että naapurihuoneiden tapahtumat jäivät läsnäolijoilta näkemättä ja kuulematta. Sotaylioikeuden käsittely olikin tältä osin ylimalkainen ja pöytäkirja lyhyt. Illan mittaan syntyi kiistaa ainakin sopivasta musiikista ja siitä, oliko jääkäreillä vai talonpoikaisarmeijalla enemmän ansiota Suomen vapauttamisessa. Säveltäjä puolusti talonpoikaisarmeijan näkökulmaa. Kuulan mielialaan vaikutti varmasti myös se, että hänen säveltämäänsä jääkärimarssia arvosteltiin julkisesti ja verrattiin Sibeliuksen vastaavaan. Kun joku läsnäolijoista huusi: "Deutschland, Deutschland über alles!' huusi Kuula vastaukseksi: "Suomi, Suomi yli kaiken!” Tämän jälkeen syntyi lisää kiistelyä, minkä seurauksena joku tokaisi Kuulalle: "Mikä sinä olet meitä arvostelemaan - mitä sinä olet tehnyt muuta kuin heiluttanut tahtipuikkoasi ryssille.” Kiivaaksi ja äkkipikaiseksi luonnehdittu Kuula suuttui tästä silmittömästi, ja pian sananvaihtoon liittyi kielikysymyskin taustana välikohtaukselle oli Kuulan lapsuuden suomalaisuusmielisyys kaksikielisessä Vaasassa. Lopputulos vihanpidosta oli se, että Kuula joutui ärsyyntyneen jääkärijoukon painostuksen kohteeksi. Jääkärivänrikki Mauritz Nylund pakotti hänet perääntymään läpi huoneen, vasten uunia. Kuula sai kasvoihinsa nyrkiniskun ja tempaisi esille pienen puukon, jolla hän veti viillon Nylundin niskaan. Tämän tapahtuman jälkeen todistajalausunnot käyvät sekaviksi eikä voida olla varmoja, mitä kaikkea Seurahuoneella tapahtui ennen ampumista ja milloin aggressiot lähtivät lopullisesti purkaantumaan. Jossain vaiheessa kuitenkin huudettiin: "Verta, verta, täällä on loukattu jääkäriä, jääkärin kunniaa on loukattu!" ja "Täällä on bolševikki! Ottakaa hänet kiinni, ampukaa! Kostakaa jääkärin veri!” Itse ampuminen tapahtui Seurahuoneen pihalla, jonka irtohiekkaan kohtaloaan pakeneva Kuula kompastui ja surmanluoti lävisti hänen päänsä. (Elmgren-Heinonen 1983, 369; Niiniluoto 1978; Paavolainen 1967, 272-273; Sarkola 27-35; Suomen Kuvalehti 30.4.1960; myös Ilta Sanomat 5.5.1958.) Yöllä säveltäjä kuljetettiin Viipurin Lääninsairaalaan, missä hänet onnistuttiin elvyttämään. Samassa sairaalassa makasi ilmeisesti myös hänen haavoittamansa vänrikki Nylund. (Ilta Sanomat, 5.5.1958; Niiniluoto 1978.)

Toivo Kuulan kuolemaan liittyvää virallista selvitystyötä on kritisoitu paljon (esim. Niiniluoto 1978; Sarkola 1960a; 1960b), sillä kuulustellut jääkärit eivät kertoneet kaikkea tietämäänsä ja tutkinta eteni hitaanlaisesti. Tutkinta toki alkoi välittömästi Viipurin raastuvanoikeudessa, joka antoi 17. päivä tammikuuta 1919 välipäätöksen. Päätöksessä mainitaan, että tutkimukset ovat keskeneräisiä, minkä jälkeen asiakirjat jätettiin maaherralle. Aikaa kului, sillä käsittelyyn palattiin seuraavan kerran vasta vuoden kuluttua, kun oikeuskansleri puuttui vitkasteluun ja määräsi alustavaksi tutkijaksi asessori Onni Petäyksen. Tämä tapahtui luultavasti Kuulan omaisten pitkällisen painostuksen jälkeen. Todistajanlausunnot olivat tässä vaiheessa entistä hatarampia ja surman jäljet kylmenneet. (Niiniluoto 1978.) 
Molemmat ampumavälikohtauksesta epäillyt henkilöt, jääkärialiupseeri Oskar Einar Pirinen ja jääkärikapteeni Pekka Heikka, kuolivat pian sisällissodan jälkeen. Pirinen sai surmansa Säiniöllä toukokuussa 1918 ja Heikka hukkui purjehdusreissulla Vaasan edustalla heinäkuussa 1921. Tutkimukset keskeytettiin tähän, ja asiakirjat palautuivat sotaylioikeudelle vuonna 1921. Sotaylioikeus antoi samana vuonna päätöksen, jossa mainitaan Pirisen ampuneen Heikan käskystä revolverilla säveltäjä Toivo Kuulaa päähän. Kyseinen vamma aiheutti säveltäjän kuoleman 18 vuorokautta myöhemmin. Muuten sotaylioikeus antoi tapahtuman raueta. (Niiniluoto 1978; Sarkola 1960a, 21, 24-27.)

\section{"Toivo KuUlaN NIMI ON PUHDISTETTAVA"}

Toivo Kuulan elämää seurannut sivistyneistö ja suomalainen lehdistö reagoivat kuolemaan välittömästi. Suhteessa Toivo Kuulan kuoleman todellisuuteen kirjoittelu oli sävyltään positiivista. Ainoastaan muutamat ruotsinkieliset lehdet kuten Dagens Press, Abo Underrättelser ja Vasabladet julkaisivat lukijoiden kirjoittamia yleisönosastotekstejä, joissa säveltäjän toimiin otettiin kantaa kriittisesti; olihan hän tunnettu myös kansallismielisistä, tulisista ja ruotsalaisvastaisista kannanotoistaan (Elmgren-Heinonen 1983, 31, 38-39, 47; Suomen Kuvalehti 30.4.1960). Kuulan kunniaa ja mainetta puolustava suomalainen rintama oli kuitenkin vahva, kuten "Asiata tunteva" ja "Pohjalainen" ilmaisevat tuntemattomaksi jäävien lehtien yleisönosastoissa (ks. seuraavat esimerkit). Julkisuudessa esitetyt kriittiset kommentit olivatkin Toivo Kuulan kuoleman yhteydessä poikkeuksia eikä lehtiä lukeva suuri yleisö reagoinut ainakaan lehtien palstoilla. Tämä on ymmärrettävää, sillä sisällissodan jälkiselvittelyt olivat Viipurissa käynnissä ja ne muodostuivat hyvin verisiksi.

"Dagens Pressin" Lucas on ottanutpuoltaakseen Toivo Kuulan surmaajan mainetta - kuolleen miehen maineen mustaamisen uhallakin. Eilen hra Lucas väittää vallan selvän tosiasian olevan, että Toivo Kuulan surmaa ei voida muka sanoa murhaksi - se on ollut korkeintaan "liioittelua hätävarjelussa (excess i nödvärn)". Sen vallan alkuasteilleen päättyneen virallisen tutkimuksen mukaan, joka asiasta toukokunssa Viipurissa pidettiin, on asia siten, että Kuula, rïtaannuttuaan eräässä jublassa olevien benkilöiden kanssa, riidan ja tappelun käännyttyä hänelle hengenvaaralliseksi, pakeni jublahuoneistosta käytävää ja portaita pitkin pihamaalle ja sitten portille päin. Mutta lähelle porttia hän kaatui, yrittäen kuitenkin ryömien kadulle. Silloin vainoojat olivat ennättäneet pihamaalle. Päallikkövallallaan he kielsivät portilla seisovaa vartiosotilasta päästämästä pakenevaa kadulle. Vainoojat saivat Kuulan kiinni. Toinen heistäpotkaisi maassa makaavaa miestä, toinen bäntä ampui. Tapabtuman nähneet kaksi sotilasta eivät voineet punttua ylempiensä toimiin. Onko tämä "liioittelua hätävarjelusta", herra Lucas? (HYK Coll. 310. 10. "Lähetettyjä kirjoituksia"/Lehti tuntematon.) 


\section{OUtI FingerRoOS}

Toivo Kuulan nimi on pubdistettava historiaa vasten siitä saastasta, joka erälltä tahoilta on sitä vastaan syydett). Rikoksen tekijä on saatava rangaistukseen. (HYK Coll. 310. 10. ’Lähetettyjä kirjoituksia"/Lehti tuntematon.)

Vähäinen yleisönosastokirjoittelu oli alkusoittoa muulle ylistyskirjoittelulle. "Lehdistön linja" oli selkeä: se ei heti paneutunut kuolinsyyn selvittämiseen vaan toimi hienovaraisesti; skandaalinkäryistä kirjoittelua esiintyi vasta 1950-luvulla (esim. Suomen Kuvalehti 30.4.1960; Ilta Sanomat 5.5.1958). Paljon ehtineen mestarin nuoruus, intohimo, taiteellisuus ja isänmaallisuus sekä tietenkin suomalaisten kokema menetys korvasivat ensimmäisinä vuosina tarkemmat yksityiskohdat. Lukijat saivat tietoonsa hyvin yleisiä sisältöjä säveltäjän taustoista ja elämäntyöstä. Vasta 1950-luku merkitsi käännettä: lukijoille kerrottiin, että seurahuoneella oli vapunaattona rankat ryyppyjuhlat ja murhaa on ympäröinyt salaperäinen mysteeri. Kolmen vuosikymmenen vaikenemisen on oltava lehdistöltä tietoinen ratkaisu, sillä muutoin eri poliittisia suuntia edustavien lehtien sivuilta löytyi sisällissodan jälkeen kauhukertomuksia vastapuolen terroriteoista. Ylipäätään lehdistössä esiintyi näinä vuosikymmeninä yksityiskohtaisia ja mielikuvia herättäviä kuvauksia rikollisista (ks. esim. Haanpää 2003, 101). Toivo Kuulan kuolema ei siis ollut sellainen murha, josta kirjoitetaan lehdissä.

Suomen nuorelle kulttuurille on tämä aika ollut ankara ballayö. Kun se siltä Kuulankin hengen riisti, taittoi se sen taimistosta ybden korjimmista, yhden joka jo oli antanut iki-arvoista enemmän kuin moni mun ja jonka tuotanto vielä varmaan olisi kehittynyt täydellisyydestä täydellisyyteen, kirk.kaudesta kirk.kauteen, sillä bän oli kuollessaan vasta 35:n vuoden ikä̈nen. (HYK Coll. 310. 10. Arvosteluja./Tampereen Sanomat, 1918.)

Päättynyt vapaustaistelu ei ole säästänyt taiteilijoitammekaan. Usea heistä on kaatunut kunnian kentälle. Kun myrsky on laannut toivomme myöskin punaisten aaltojen tyyntyvän. Siksipä oli niin uskomattoman yllättävä tieto Toivo Kuulaa kohdanneesta onnettomundesta. Kohtalo ei ole meitä armahtanut, vaikka kyseessä oli meille niin kallis henki. (HYK Coll. 310. 10. Arvosteluja./ Karjala, 19.5.1918.)

Järisyttävän onnettomunden ubriksi V ï̈purissa joutuneen säveltäjä Toivo Kuulan hautaus tapabtui täällä eilen, muodostuen ylentäväksi jublallisundeksi, joka osoitti kuinka syvää kaipausta suurilabjaisen taiteilijan äkillinen poismeno on aibeuttanut. (HYK Coll. 310. 10. Arvosteluja./Lehti tuntematon.)

Lehdistön suojeleva reaktio osoittaa, että Toivo Kuulan kuolema oli erityisellä tavalla poikkeava: vaiettu murha vailla arvon ja kunnian riistoa. Kuula oli sekä valkoisen että punaisen lehdistön varjeluksessa. Hänet samaistettiin valkoisiin, joille järjestettiin sankarihautajaisia ja veisattiin kiitosta, mutta silti punainenkin lehdistö ylisti hänen ansioitaan. Poikkeuksellisen kuoleman ja muistin käsittely politisoituivat: ei-toivo- 
tut äänet vaiennettiin ja tilalle asetettiin entistä ehompi suomalaisuus (ks. myös Fingerroos 2004; Peltonen 2003; Portelli 2003a; 2003b). Yhteisö harjoitti identiteettipeliä myytillistääkseen oman menneisyytensä ja perustellakseen olemassaolonsa:

Hänen järkyttävästä kuolemasta ei meillä ole paljon tietoja, emmekä tarvitsekaan munta kuin ybden: niin kuin hän elämässään koko olemukseltaan ja sielultaan oli suomalainen, nïn hän myös sankari-kuolemansa hetkellä taisteli ja kaatui suomalaisena. (HYK Coll. 310. 10. Alma Kuulalle toimitettu kirje.)

Tietyistä totuuksista vaikeneminen ja valikoiva muisti olivat Toivo Kuulan kuoleman yhteydessä vallankäytön välineitä. Kuolema oli kansallinen ja arvoperusteinen ongelma, johon reagoitiin jääkäriliikkeen sisällä sopivalla voiman ja rivien yhtenäisyyden näytöllä - ja muutoin vaikenemalla. Nämä toimet mahdollistivat suuren suomalaisen myytin rakentamisen. Toivo Kuula haudattiinkin Helsingin Hietaniemen vanhalle hautausmaalle toukokuussa 1918, ja haudalle pystytettiin Alpo Sailon veistämä muistopatsas vuonna 1922. Hautajaispäivänä rautatieasemalle oli kokoontunut joukko ystäviä, omaisia ja ulkopuolisia uteliaita vastaanottamaan vainajaa. Kukkien peittämä valkoinen arkku nostettiin ulos kuusenoksilla koristellusta vaunusta, ja hautajaissaatto lähti etenemään kohti Vanhaa kirkkoa, jonka edustalla oli lisää yleisöä odottamassa. Sisälle kirkkoon, mustiin verhotulle alttarille, vainajan saatteli Kuulan oman surumarssin soidessa suomalaisen säveltaiteen kerma: professori Robert Kajanus, säveltäjät Selim Palmgren, Otto Kotilainen, Leevi Madetoja, Arvo Maasalo ja Yrjö Kilpinen. Siunaus päättyi Suomen kuoron esittämään lauluun, seppeleenlaskuun ja professori Kajanuksen juhlapuheeseen. (HYK Coll. 310. 10. Arvosteluja./Lehti tuntematon.)

Paradoksaalista säveltäjämestarin kuolemaan johtaneissa tapahtumissa oli se, että Toivo Kuula ja jääkärit olivat isänmaan parasta ainesta: sankareita, joiden palvonta ohitti vapunyön todellisuuden (vrt. Portelli 2003a, 29-41; 2003b). Muistotyössä Suomi oli yli kaiken, ja Kuulan suomalaisuudelle pohjalaisuus antoi ylimääräisen lisän. Myyttiä on rakennettu vuosikymmeniä, sillä varsinkin Tuomi Elmgren-Heinonen liittää 1960-luvulla rakentamassaan henkilökuvassa Toivo Kuulaan kaikki pohjalaisen miehen heimostereotypiat: Kuula oli voimakas, omanarvontuntoinen, isosanainen, olemukseltaan komea ja taipuvainen musikaalisuuteen (ks. Vilkuna 1969, 170). Myös herraviha eli ylempiä vastaan osoitettu kiukku (Apo 1986, 244; Haanpää 2003, 108-112) kuuluivat Kuulan hyveisiin jo nuorena: "Ja kukapa sitten olisi paremmin soveltunut suomalaisten poikien päälliköksi johtamaan lumi- ja kivisotaa ruotsalaisia vastaan, kukapa olisi ollut intiaanileirien johtaja, kuka marssinut poikakomppanian etunenässä, kun se sotilaslauluja laulaen lähti Ahvensaareen kalaan, tai kukapa olisi tappelussa ajanut toverinsa äitiensä helmoihin eikä pelännyt sylipainia kasarmin sotilaidenkaan kanssa, ellei tuittupäinen lyseolainen Toivo Timoteus?” (Elmgren-Heinonen 1993, 31.) 


\section{OUtI FingerRoOS}

\section{"Olin VIIPURISSA SINÄ YÖNÄ JONA MURHA TAPAHTUI"}

Suomen Kuvalehti julkaisi 30. huhtikuuta 1960 näyttävän kirjoituksen, jonka otsikon mukaan Toivo Kuulan kuolemaan liittyvä vanha mysteeri on selviämässä. Siinä Riku Sarkola, samainen mies joka julkaisi kirjan Toivo Kuulan matkanpää (1960), julistaa, että neljäkymmentäkaksi vuotta sitten kajahtaneen laukauksen kaiku kiirii vielä tänäkin päivänä keskuudessamme. Ääni ei vaimene, koska laukauksesta alkoi pitkä vääryyksien sarja, jota ei ole vieläkään hyvitetty. Mielenkiintoista tässä on se, että 1960-luku näyttää olleen kypsä monenlaisille sisällissodan totuuksille. Sarkola käsittelee Toivo Kuulan kuolemaa yhtä näyttävästi kuin Väinö Linna Koskeloiden kohtaloita Pentinkulma-trilogiassa ja akateeminen historiankirjoitus punaista sotaa (esim. Paasivirta 1957; Paavolainen 1966; 1967; 1971).

Riku Sarkolan tekstissä on runsaasti otteita Alma Kuulan päiväkirjasta, joita on täydennetty "eräillä uusilla tosiasioilla". Sarkolan päämotiivina on todistaa, että mysteeriin ratkaisemiseksi ilmaantuu koko ajan uusia piirteitä. Vaikka vaikutusvaltaiset henkilöt yrittivät painostuksellaan jättää "tämän kuohuttavan teon" vaille tuomioistuimen käsittelyä, molempien syytettyjen nimet ovat toimituksen tiedossa. Tästä syystä lehti toivoo lukijoilta lisää todistusaineistoa: 'Pyydämme niitä, jotka tietävät tapahtumista joitakin tosiasioita, niistä meille kirjoittamaan.” (Sarkola 1960b.) Sarkolan tekstin perässä on vielä yleinen vetoomus muistoaineiston talteen keräämiseksi: "Toivo-Kuula-Seura on päättänyt koota ja säilyttää museoon tai museo-osastoon Toivo Kuulan muistoaineistoa katsojia ja tutkijoita varten." (Suomen Kuvalehti 30.4.1960.) Lehden julkaisema vetoomus on kuin kopio Työväen muistitietotoimikunnan (TA) tai Kansanrunousarkiston (SKS) keruukehotuksista vuoden 1918 muiston tallentamiseksi (ks. Fingerroos 2004, 68-78; Peltonen 1996, 65-90).

Kirjoitus- ja keruukehotuksen innoittamana muutama muistelija lähetti Suomen Kuvalehdelle tekstejään. Mistään laajasta keruusta ei siis ollut kyse, mikä on ymmärrettävää, sillä yölliselle tapahtumalle oli vähän ulkopuolisia näkijöitä ja jääkärien vaikenemisen muuri piti. Helsinkiläinen komentajakapteeni Erkki Ainamo kirjoitti Toivo Kunlan ampumistapauksesta (HYK Coll. 310. 14.). Ainamo oli lokakuussa 1948 hoidettavana Tilkan sotilassairaalassa ja sai huonetoverikseen everstiluutnantti Laakson. Tämä uskoutui Ainamolle, sillä hänellä oli Seurahuoneen tapahtumista paljon mieltä painavaa asiaa. Ainamo kirjoitti keskustelun ylös vasta kotiin pääsynsä jälkeen, sillä hän ei katsonut voivansa tehdä muistiinpanoja intiimissä keskustelutilanteessa. Suomen Kuvalebdelle hän toimittaa tietonsa "mitä suurimmalla varauksella".

Erkki Ainamon kirjaama kuvaus illan alusta vastaa melko tarkasti viranomaisraporttia: Kuula jäi juhlapaikalle ilman vaimoaan, joi runsaasti, riehaantui, kiivastui, alkoi tapella ja tempaisi esiin puukkonsa, jolla "viilsi erään ruotsalaisen takin rintamukseen haavan, joka ulottui kylkiluihin saakka. Eräs toinen, joka yritti tulla väliin, sai piston käsivarteensa”. Tässä vaiheessa muut paikallaolijat kävivät käsiksi Kuulaan ja katsoivat parhaaksi poistaa hänet tilaisuudesta. Tehtävä annet- 


\section{"KuULAA KALLOON"}

tiin Mäkiselle ja Laaksolle. Kuula kuitenkin harasi ankarasti vastaan: Ajoittain hän seurasi suosiolla ryhtyäkseen hetken perästä rimpuilemaan päästäkseen vapaaksi. Lopulta saattajien onnistui viedä Kuula pois juhlapaikalta, minkä jälkeen he päästivät hänet irti. Kuula kääntyi saman tien ympäri ja lähti juosten takaisin. Tätä seurannut ampumavälikohtaus jäi Laaksolta näkemättä. Ainamo päättää tekstin toteamalla, että vaikka Kuulan käytös ei lievennä surmaajan tekoa, "on sittenkin kyseenalaista onko syytä saattaa kaunistelematonta totuutta julkisuuteen":

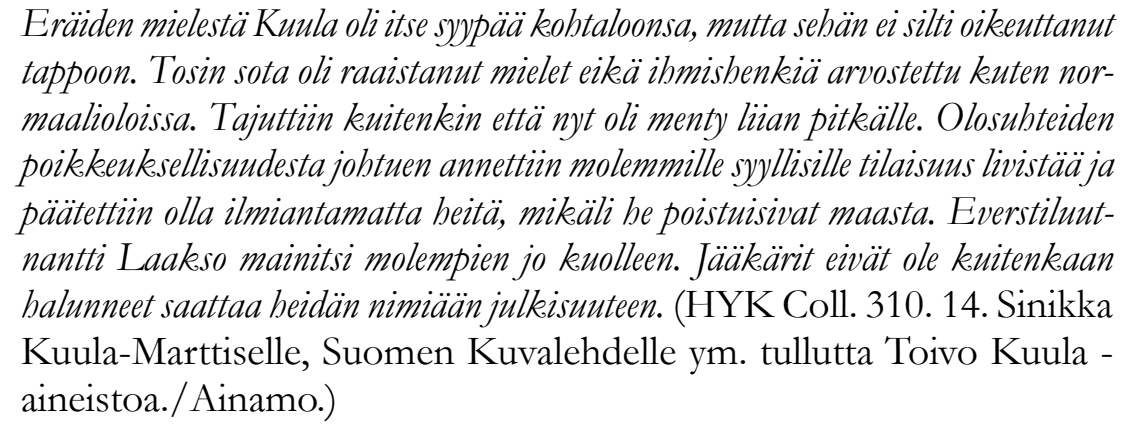

Suomen Kuvalehden "Arvoisa toimitus" sai vuonna 1960 toisenkin kirjeen, jossa kirjoitushetkellä 50-vuotias silminnäkijä kertoo lukeneensa lehdestä 'Toivo Kuulaa kuvaavan mysteerion”. Hän oli tapahtumahetkellä viettämässä syntymäpäiviä Viipurissa ja siksi majoittuneena pieneen huoneeseen Seurahuoneen alakerrassa. Ikkunat olivat kadulle päin. Hänen kuvauksensa poikkeaa melkoisesti edellisestä, sillä "Lapsen uteliaisuudella seurasimme seurahuoneella elämän menoa":

Ei Kunlaa pihalla ammuttu, vaan pöydän päähän lyyhistyi, ensimmäisen laukaukesen kajahdettua. Silloin me nopeasti juoksimme alakertaan sanomaan äidille että sotilaspukuinen lybyt mies ampui tumman miehen. Hetken päästä kolkutettïn meidän asunto-ovelle ja me pelättïn hirveästi. Olimme hiljaa... askeleet etenivät pitkin käytävää. Silloin äiti avasi hiljaa oven ja kurkisti, näki lybyen miehen asetakissa menevän, humalaisen horjuvin askelin. (HYK Coll. 310. 14. Kirje Suomen Kuvalehdelle 3.6.1960.)

Myös pianisti Sinikka Kuula vastaanotti vuonna 1960 kirjeen, jossa muistelija A. Laitinen esittää oman totuutensa: "Olin Viipurissa silloin majoituslautakunnassa, sinä yönä jona murha tapahtui." Laitinen oli hotelli Belvederessä vahtivuorossa, jonne paikalle saapui kaksi upseeria. Toinen, kapteenipukuinen, kysyi komendantti Rautakaria, joka ei kuitenkaan ollut tavattavissa enää siihen kellonaikaan. Samainen mies tiedusteli Laitiselta mahdollisuutta tehdä kumppanilleen ruumiintarkastuksen: "[K]ysymys oli saada selville Toivo Kuulaa koskeva tapaus. Koska Toivo Kuula on Raatihuoneella joku hetki ammuttu." Kun ruumiintarkastus oli tehty, kapteeni otti vielä Pakkalan pistoolin ja peilasi asetta vasten valoa; sillä ei ollut ammuttu. Tämän toimituksen jälkeen kapteeninpukuinen ja Pakkala poistuivat Belvederestä. Laitinen arvioi, että olemukseltaan laihahko, noin 180 senttimetriä pitkä kapteeni oli 


\section{OUtI FingerRoOS}

iältään 30. Vääpeli Pakkalaa hän kuvaa viitisen vuotta vanhemmaksi, tukevaksi ja 165 senttimetriä pitkäksi. Belvederen tapahtumien sisältöä Laitinen alkoi epäillä vasta jälkeenpäin, kun hän luki sanomalehdessä asiaa koskevan kirjoituksen ja näki hermostuneen kapteenin Punaisenlähteentorilla. "Oliko tuo tarkastus vaan muodollinen ja paljon mahdollista - itse syyntakainen." (HYK Coll. 310. 14. Kirje A. Laitiselta Sinikka Kuulalle. 29.8.1960.)

Kolmen silminnäkijän muistot antavat Seurahuoneen tapahtumille huomattavasti lisäsävyjä, mutta tapahtumien kulku ei selvene. Ensimmäinen kuvaa, miten hänen huonetoverinsa osoittautui Seurahuoneen vapaudenjuhlijaksi, joka vieläpä saattoi puukon kanssa riehuneen säveltäjä kauas sisätiloista. Ampumista kyseinen everstiluutnantti ei kuitenkaan ollut nähnyt vaan vihjasi, että illan tapahtumien yksityiskohdista vaiettiin jääkäripiireissä yhteistuumin. Kahdeksanvuotias pikkutyttö, joka seurasi isojen miesten juhlintaa ovensuussa, väittää ampumisen tapahtuneen sisätiloissa ja Kuulan lyyhistyneen laukauksen jälkeen pöydän päähän. Sen jälkeen tytön äiti näki lihavahkon, lyhyen ja humalaisen miehen pakenevan Seurahuoneelta takakautta. Kolmannen muistelijan kuvauksessa esiintyy jälleen tukeva mies, jolle toinen, vääpelinpukuinen, suoritti tuloksettoman ruumiintarkastuksen, Toivo Kuulan murhasta epäiltynä.

Muistitietoon Toivo Kuulan kuolemasta liittyykin niin paljon epäselvyyttä, että punaista lankaa on mahdoton seurata 1960-luvulla kirjoitetun lähdeaineiston perusteella. Muistitieto on eräänlainen cocktail kollektiivisia aihelmia, jokaisen kirjoittajan henkilökohtaisia motiiveja, kokemuskerrontaa ja omakohtaisia (historian)tulkintoja. Muistitieto sisältää merkityksiä, joiden avulla muistelijat ilmaisevat suhteensa ja kantansa kuuluisan säveltäjämestarin vaiettuun kuolintapahtumaan. (Ks. Haanpää 2003; 98-99; Peltonen 1996, 38-41; Ukkonen 2000, 30-31.) Sama päätelmä toki liittyy muihinkin lähteisiin kuten lehtikirjoitteluun ja Elmgren-Heinosen Toivo Kuula -elämäkertaan. Kuolintapa oli niin poikkeuksellinen, että kerronta ja muisti sisältävät lukemattomia yksilöllisiä tulkintoja. Jokaisella asianomaisella on oma näkemyksensä tapahtumien kulusta, kaikki eivät sitä suostu kertomaan. Tästä syystä Kuulan kuolemaa ei ole järkevää tulkita valmiista muotista käsin, sillä kuolema oli toisenlainen. Sen sijaan muistelijoiden subjektiivisista aineksista rakentuu täysin omanlaisensa ja lopulta epäselväksi jäävä sisällissodan 1918 kuolintapaus.

\section{"TÄNÄÄN ALKAA MINUN TUHATVUOTINEN VALTAKUNTANI. JULISTAKAA SE MAAILMALLE."}

Toivo Kuulan elämää sävyttivät ristiriidat ja kansallisromantiikan ajan taiteilijoille tyypilliset itsetutkiskelut, luonnossa samoamiset ja heräämiset. Uskonto ja kuolema kulkivat hänen mukanaan läpi elämän kuolinvuoteen houreisiin asti, mistä tämän luvun otsikkokin on esimerkki. Matti Kuulan isähahmoon sisältyi voimakkai-

ta, uskonnolliseen johtajuuteen viittaavia piirteitä, sillä hän piti lestadiolaisessa 


\section{"KuULAA KALLOON"}

kodissaan seuroja ja puheita ja rakasti hengellistä musiikkia. Myös äiti, Susanna os. Vehkakoski, kuului herätyksen piiriin, joten Toivo Kuulan kotikasvatukseen kuului vakavan uskonnollisuuden henki. (Elmgren-Heinonen 1983, 15-22.) Kuoleman teemasta tuli osa Toivo Kuulan elämää ja sävellystyötä viimeistään siinä vaiheessa, kun hän hautasi ensimmäisessä avioliitossaan syntyneen tyttärensä Aunen Saarijärvelle. Riku Sarkola $(1960,48)$ kirjoittaa synkästä hautausmatkasta: "Kuolleen lapsen arkku kainalossaan hän sai samota useita peninkulmia metsiä ja rämeitä etäiselle kirkolle.” Pian tämän jälkeen Kuula sävelsi sekakuorolaulun Tunti lasta tuonelaan ja yksinlaulun Kesäyö kirkekomaalla (Wikipedia [online], 27.1.2005).

Edellistä taustaa vasten on kiinnostavaa, että kuolema kietoi Toivo Kuulan vaimon, laulajatar Alma Kuulan pysyvästi raskaaseen viittaansa. Rakastava vaimo vietti miehensä kuolinvuoteen äärellä kaikki ne päivät, jolloin säveltäjä häilyi elämän ja kuoleman rajamailla. Hän oli toimintakyvytön ja avuton jopa siinä määrin, että lääkärit huolestuivat hänen terveydentilastaan. Hän uskoi miehensä selviämiseen ja suunnitteli toimivansa halvaantuneen säveltäjän hoitajattarena. Lisäksi hän kirjoitti ylös miehensä sekavat houreet ja valvoi, ikään kuin se olisi hänen ainoa elämäntehtävänsä:

Ah niütä kauheita hetkï̈ sairastuneen luona, niitä tuskallisia, raatelevia, epätoi-
voisia päiviä! Sydän se oli haljeta murheesta, kärsin kai melkein yhtäpaljon kuin
Toivoni. Istua vieressä, odottaa tuleeko käännös parempaan, vai ei, nähdä taiste-
lua elämästä ja kuolemasta, toivoa ja taas joutua epätoivoon, nähdä omansa
rumentuneen, kärsivän näköisenä, pää sidottuna, vasen puoli ruumïsta halvattuna.
Ja sitten nähdä hänen vähitellen riutuvan, nähdä kuoleman kaamean hetken lä-
hestyvän, eikä voida tehdä mitään kuin koettaa lohduttaa omaani, ainoatani,
vaikka itse olin monesti pyörtymäisilläni. Ja kuoleman sormi kosketti hänen
kaarevaa otsaansa, pois menin kultainen elämä, ikuisen kevään asunnoille. Mi-
nua jäi sammuva silmä vielä katsomaan ja Anni sanoi hän vielä vähän ennen
vïme hengähdystään. (HYK Coll. 310. 11. Alma Kuulan päiväkirja.)

Päiväkirjamerkintöjen perusteella Alma Kuula koki voimakkaan ahdistavana myös sen vaikenemisen ilmapiiriin, johon hän törmäsi ensimmäisen kerran kuolemaa seuranneena aamuna kaupungilla. Julkinen vaikeneminen jatkui vuosia ja varjosti Alma Kuulan elämää erityisesti. Hän kuvaa päiväkirjassaan yksityiskohtaisesti, kuinka lähti heti herättyään hakemaan miestään Vaasan rykmentin II pataljoonan esikunnasta. Rykmentin upseerit olivat tavoittamattomissa suljettujen ovien takana, eikä säveltäjä Kuula ollut vahdissa olleiden sotilaiden mukaan yöpynyt esikunnan tiloissa. Eräältä senitääriltä Rouva Kuula kertoo saaneensa epämääräisen kehotuksen mennä Seurahuoneelle kaupunginkomendantti Finnen luo. "Vähän oudoksuen tätä" hän juoksi seurahuoneelle kysyen ovenvartijalta ja tarjoilijattarilta, onko kapellimestari käynyt siellä. He vastasivat kielteisesti. Tämän jälkeen rouva Kuula pyrki yläkertaan, jossa kaupunginkomendantin kerrottiin olevan. Matkalla vastaan tullut sotilas ennätti selvittää totuuden: 


\section{OUtI FingerRoOS}

$[\mathrm{H}]$ än sanoi aivan raa'asti: 'Yksi Kunla ammuttiin täällä viime yönä.' Putosin aivan kivettyneenä portaille ja heräsin vasta alhaalla kun minut oli viety jonkin tarjoilijattaren buoneeseen ja lääkäri seisoi vieressäni. (HYK Coll. 310. 11. Alma Kuulan päiväkirja.)

Alma Kuulan surutyö oli perusteellista ja vei laulajattaren lopulta mukanaan: hän ei jälkeenpäinkään pyrkinyt kokemuksistaan eroon vaan sääli itseään ja kohtaloaan. Päiväkirjateksteistä ei löydy viitettäkään siitä, että juhlinta oli seurahuoneella rankkaa ja Toivo Kuula juopuneessa tilassa. Sen sijaan Alma Kuula syyttää jääkäreitä siitä, ettei "yksikään tule puhumaan kuinka se on käynyt, eikä yksikään heistä kirjoita ainoatakaan riviä minulle poloiselle". Tytär Sinikka oli koko tämän ajan hoidettavana, ja kun hän saapui sairaalaan, sureva äiti pyörtyi uupumuksesta. Alma Kuula ei siis toipunut miehensä kuolemasta, ja alistunut surumielisyys sävytti hänen loppuelämäänsä: "Poissa on minun onneni nyt, poissa rauhani, poissa osa sielustani ja synkän syksyn kaltainen on elämäni nyt.” (HYK Coll. 310. 11. Alma Kuulan päiväkirja; Elmgren-Heinonen 1993, 379.)

Alma Kuula oli paneutuvassa surussaan suorastaan marttyyri, kuin Lemminkäisen äiti Tuonelan virran rannalla odottamassa, että hän, joka ei vielä hengitä, virkoaisi ja osoittaisi merkkejä elämänvoimasta. Vertaus on liioiteltu, mutta analogia tulee väistämättä mieleen päiväkirjamerkintöjä lukiessa. Kaiken lisäksi Akseli Gallen-Kallelan Lemminkäisen äiti muistuttaa erehdyttävästi valokuvaa, joka on otettu sairaalassa neljä päivää ennen Toivo Kuulan kuolemaa. Alma Kuula istuu rautasängyn äärellä pidellen miehensä käsiä. Tausta on harmaa, potilas puettu valkoisiin ja hänen kasvonsa valkoisen liinan peitossa. Kuvaa katsellessa voi melkein kuvitella, millaisen tunnelman sairaan hourailu loi kyseiseen päivään: "Eikös hiiret ole tavallisesti mustia? Mutta mitä merkitsee valkoinen hiiri? Eikö se ole kuolemaa?" (HYK Coll 310. 12. Alma Kuulan muistelmia Toivo Kuulasta.) Alma Kuulan päiväkirjasuru muistuttaa myös inkeriläisten itkijänaisten tai lyyrisen kansanrunouden valituksia. Hänen kirjaama huolensa on kuin lyyrinen teksti, jonka välityksellä voi ilmaista, miltä suru tuntuu ja miten kokonaisvaltaisesti se vaikuttaa ruumiissa ja mielessä. (Timonen 2004, 310-311.) Päiväkirjamerkinnät ovat eräänlaista lauluttoman ajan lyriikkaa (Laitinen 1997, 210), sillä ilmaisuun tiivistyy huoli oman miehen kuolettamisesta (Utriainen 1999), itsestä, Sinikasta, kuoleman epäselvyydestä ja tulevasta:

Verellä tabtoisin nämät sanat kirjoittaa, Toivoni, rakkeaimpani, ainoani on surmattu, byvä Jumala, surmattu mitä racimmalla tavalla, läpi pään, läpi aivojen ammuttu ja potkittu ja tämän ovat tehneet omat miehet, meidän Suomemme kansan "parempi aines". Voi rakas isä, kuinka tämä voi olla mahdollista, että hän punaisilta säästyi Sämiöllä ollessamme ja valkeeat, tai toisin sanoen jääkärit hänet surmasivat, hänet, joka beille Vappuna piti innostuneista pubeita ja joka oli täydellisesti rauhan mies! Eivät tienneet nuo vieläkin tuntemattomat konnat, että kansansa tulee heitä vieläjälestäpäin kiroamaan, silläybden kansansa parbaista supisuomalaisista pojista he kaatoivat, säälimättä, tuntematta mitään ibmisyyt- 
tä, ajaen kuin koiran bänet piballe. Ja minulta he ovat rïstäneet omani, koko elämäni, toisen puolen sieluani sekäpieneltä Sinikalta bänen isä kultansa. (HYK Coll. 310.11. Alma Kuulan päiväkirja.)

Naisen ja kärsijän rooliin eläytyminen on lopulta niin perusteellista, että Alma Kuulan oma elämä on menettämässä mielekkyytensä: 'Ei, tämä ei voi olla mahdollista, että minä nyt olen yksin maailmassa, ilman veriystävääni, rakkaintani. Ei koskaan hän enää palaa, vaan nurmen alla nukkuu valkeassa arkussaan. Voi että jätit minut, eikä yhdessä saada kuolla, yhdessä painaa silmä umpeen, yhdessä päättää mainen elämä!” (Nenola-Kallio 1982, 99-106; HYK Coll. 310. 11. Alma Kuulan päiväkirja.)

Kuuluisa surijatar oli lehdistön erityisessä suojeluksessa. Itse asiassa Alma Kuulasta tehtiin suurempi ihminen kuin sureva nainen, hän oli suomalainen nainen. Toivo Kuulan muistokonserteista julkaistiin keväällä 1919 viljalti arvioita ympäri Suomen. Niissä ylistettiin paitsi säveltäjämestarin mestarillisuutta myös rouvan tulkinnan harvinaislaatuista syvyyttä. Kielikuvat tavoittelivat elämää suurempia arvoja ja täyttyivät suomalaiskansallisella ja mytologisella jargonilla. Koska Toivo Kuulan muisto oli myytillistynyt, tuo ahkerasti konsertoiva ja muinaisuuden kätköistä esille astunut surutar oli Suuren suomalaisen miehen paras tulkki. Alma ja Toivo Kuula olivat ideaaleja kohteita suomalaiskansalliselle ja poliittisesti virittyneelle palvonnalle.

Valkoisia kukekia. Vibko vihon perästä. Nïn, juuri valkoisia siellä tulikin olla. Nebän parhaiten tunnelmaa kuvastivat. Olihan nyt surujubla, liian varbain manan majalle menneen säveltäjän muistojubla. Ja heti kun laulajatar ensi kerran esille astui, laskeutui buoneeseen kuin surun pybä hartaus. Surun, joka syvimmin oli kobdannut laulajatarta itseään, mutta joka läheltä oli viiltänyt kuulijainkin sydämiä. Siksi sävelet, jotka sydämestä läbtivät, löysivät tiensä suoraan kuulijain sydämïn. [..] Ja miten suomalainen oli koko ilta! Vain yksi saksankielisin sanoin sävelletty laulu, munten vain suomalaisia runoja. Ja suomalainen kansansävel kaikui kaiken pohjana. Suomalaiset kotoiset sävelet välähtelivät sielun silmissä näitä suomalaisia säveleitä kuullessa. Ja miten suomalainen oli laulajatar itsekin vaatimattomana mustassa puvussaan. Kuin olisi itse surutar muinaisuutemme kätköstä astunut esiin. (HYK Coll. 310. 10. Arvosteluja./ Suomen Nainen.)

\section{VAIETKAA: "TÄMÄN OVAT TEHNEET OMAT MIEHET"}

Toivo Kuulan kuoleman ympärille kietoutuu sikermä teemoja, joita artikkelissa on lyhyesti esitelty. Kuoleman mysteeri liittyy suomalaismielisten sankarien keskinäiseen välienselvittelyyn ja kuolemanhetkellä tapahtuneeseen kunnian riistoon. Oikeammin kyse oli paradoksista ja ongelmasta: kunniallisten miesten hetkellisestä 


\section{OUtI FingerRoOS}

kunniattomuudesta. Vallinneissa olosuhteissa tapahtumille oli mahdoton löytää käypää selitystä. Totuudesta vaikeneminen oli ainoa toimiva strategia, sillä kuuluisa säveltäjä käyttäytyi samaan tapaan kuin stereotypian mukainen eteläpohjalainen puukkojunkkari: hän puolusti talollisarmeijan kunniaa jääkäreiden kustannuksella. Hänen toimiensa voi tulkita olleen eräänlaista jaloa taistoa aidon suomalaisuuden puolesta - kuitenkin sillä erotuksella, että riehuminen jääkäreiden voitonjuhlassa ei tarjonnut aineksia samanlaiselle kerskailevalle sankaruudelle kuin esimerkiksi eteläpohjalaisten junkkarien häätapot (ks. Haanpää 2002; Vilkuna 1949; Ylikangas 1976).

Sanomalehtikirjoitukset osoittavat, että Suomen kansa yhdistyy kun Toivo Kuulan kaltainen suomalainen mies kuolee. Etenkin pohjalaiseen suuhun sana murha sopi hyvin, sillä surmanilta oli "tavallaan aito suomalainen pirunpolska (Niiniluoto 1978)". Ampumisesta syyllistettiin "Suomemme kansan 'parempi aines"', eikä se jää "kostamatta pohjalaisilta, jos ei siitä selvää saada muuten" kirjoittaa Alma Kuula (HYK Coll 310. 11.). Toisaalta Toivo Kuula kuului itsekin parempaan suomalaiseen ainekseen. Siksi muistokirjoituksissa puhutaan valitettavasta murhasta ja ampumisesta, turmasta ja väkivaltaisesta kohtalosta (esim. HYK Coll. 310.10. Arvosteluja./Kotilainen; Väinö S-n). Toivo Kuula siis siirtyi lehdistön valikoivan muistin avulla myyttiseksi hahmoksi suomalaiskansallisten ikonien galleriaan, ja murhaan liittyvä kerronta politisoitui (myös Portelli 2001; 2003a; 2003b). Kuolinhetkestä alkoi prosessointi, jonka tehtävänä oli pitää muisto mahdollisimman puhtaana ja ylevänä. Hänen hahmonsa kuviteltiin nostattavan kansan hengen ja kyläkirkkojen jumalanpalveluksissa viriävät äänet sellaisiin korkeuksiin, että ne 'leviävät yli koko tienoon ja kuuluttavat niin vanhoille kuin nuorillekin legendaa suurista sielunkärsimyksistä", kuten professori A. Rudnev tunnelmoi muistokirjoituksessaan (HYK Coll 310. 10. Arvosteluja; politisoitumisesta ks. myös Anttonen 1996).

Toivo Kuulan kunniaa ei riistetty pois kuin hetkeksi. Salaaminen alkoi heti yön tunteina. Kun puoliso Alma Kuula etsi miestään, totuutta ei enää ollut. Kuulan kuolema ja hautajaiset sen sijaan olivat suuren kansallisen surujuhlan aihe, joten kuolintapahtuma asettui erilleen sitä seuranneesta ritualismista. Surutyölläkin oli tendenssinsä, sillä pohjalaisen, herätyskristillisyyden riveistä nousseen säveltäjämestarin kilpeä kiillotettiin uskonnollisilla ja kalevalaiseen suomalaisuuteen viittaavilla teemoilla. Niistä etsittiin selitystä kuoleman mysteerille. Esimerkiksi Hämärän laulun todettiin muistuttavan lestadiolaisia suruvoittoisia, syvästi uskonnollisia lauluja (HYK Coll. 310. 10. Arvosteluja./Otava 1918). Jopa työväenlehdistö kirjoitti kuolemasta kunnioittaen ja raamatulliseen sävyyn. Itä-Suomen Työmies (HYK Coll. 310. 10. Arvosteluja) käyttää metaforaa tuonen viikatteesta, joka on leikannut viimeisten kuukausien aikana runsasta satoa ja katkaissut viimeksi kuuluisan säveltäjän elämänlangan "saattaen Suomen säveltaiteen hengettären surupukuun". Työn Valta nimeää Kuulan väkivaltaisen ja Kainin merkeissä kulkevan ajan uhriksi: 


\section{"KuULAA KALLOON"}

Köyhemmäksi on nyt käynyt Suomessa Väinämösen kannel, kun sinä oletpoissa, Toivo Kuula, mutta niin kauan kun se belk.kyy, on siinä myös aina belkkyyvä sinun hopeinen sydänkielesi, ja kansasi on siunaava elämäntyösi lobduttavaa kauneutta. (HYK Coll. 310. 10. Arvosteluja./Työn Valta.)

Säveltäjä Toivo Kuulan kuolema oli traaginen, väkivaltainen ja ristiriitainen. Suomalaisuuden-, voiton- ja kunniantunto olivat Viipurin keväässä 1918 kuitenkin niin korkeassa kurssissa, että voittajien lippu sai liehua linnan tornissa valkoisena ja puhtoisena. Näin syntyi myytti ja mysteeri.

\section{VIITTEET}

1. Keskustelu muistitietohistorian epistemologisista eli tietoteoreettisista ulottuvuuksista on perua Turun yliopiston folkloristiikan kahvihuoneessa keväältä 2004 käydystä harvinaisen hedelmällisestä keskustelusta. Kahvihuoneen ilmoitustaululle piirtyi kolmikulmio, jonka synnyssä minulla ja Taina Ukkosella on näin "jälkeenpäin muistellessa" hieman nokitteleva "munan ja kanan" -rooli. Itse sijoitan muistitietohistorian epistemologian suoraan Habermasin tietoteoreettiselle pohjalle, jolloin kolmion haaroina ovat 1.) selittävä muistitietohistoria, 2.) tulkitseva eli hermeneuttinen muistitietohistoria ja 3.) kriittis-emansipatorinen muistitietohistoria. (Habermas 1976, 130-133; myös Niiniluoto 1980, 70-73; Fornäs 1998, 22; Fingerroos 2004, 82-83.) Taina Ukkonen korvaa selittävän muistitietohistorian termillä realistinen muistitietohistoria ja tulkitsevan historiallis-hermeneuttisella. Käytännössä muistitietohistorian epistemologinen kolmikulmio rakentuu näiden ainesten summana. Toisin sanoen oral history -tutkimuksissa voi olla pelkistetysti kolmenlaisia tietoteoreettisia päämääriä.

1. Realistinen tai selittävä muistitietohistoria pyrkii totuuteen, selittämään ilmiöitä tai rakentamaan kausaliteetteja. Lähestymistapaan voi liittyä tekninen tiedonintressi (Niiniluoto 1980, 70-73). Yhtä hyvin tutkimus voi olla luonteeltaan empiiris-analyyttista (esimerkiksi lähellä mikrohistoriaa oleva muistitietohistoria).

2. Ymmärtävä tai historiallis-hermeneuttinen muistitietohistoria pyrkii tulkintaan. Lähestymistapaan liittyy praktinen tiedonintressi (Niiniluoto 1980, 70-73).

3. Kriittis-emansipatorinen muistitietohistoria pyrkii tulkintaan kriittisesti ja emansipatorisesti. Lähestymistapaan liittyy praktinen tiedonintressi (Niiniluoto 1980, 70-73), ja raja ymmärtävään tutkimukseen on lähinnä määrittelykysymys.

Käytännössä tutkimukset liikkuvat kolmikulmion sektoreilla joustavasti. Lisäksi on huomioitava, että muistelu voi olla tutkimuksen kohde ja lähde, mikä mutkistaa mallia edelleen. 


\section{OUtI FingerRoOS}

2. Tapahtumasta löytyy selvä analogia italialaisen tehdastyöläisen Luigi Trastullin poikkeukselliseen kuolemaan liittyvään moninaiseen, värittyneeseen ja poliittisesti latautuneeseen muistiin, mitä kompleksia Alessandro Portelli purkaa ja analysoi kerros kerrokselta samannimisessä kirjassaan (ks. Portelli 2001).

\section{TutKIMUSAINEISTOT}

\section{Arkistolähteet}

Helsingin yliopiston kirjasto, käsikirjoituskokoelmat. Toivo Kuulan henkilöarkisto. HYK Coll. 310.10. Kirja otsikolla: "Arvosteluja. Toivo Kuula."

HYK Coll. 310.11. Vihko otsikolla: "Alma Kuulan päiväkirja 1.2.1914-25.12.1919." HYK Coll 310. 12. Vihko otsikolla: "Alma Kuulan muistelmia Toivo Kuulasta." HYK Coll 310. 14. Kirjekuorin otsikolla: "Sinikka Kuula-Marttiselle, Suomen Kuvalehdelle ym. tullutta Toivo Kuula aineistoa."

— Komentajakapteeni Erkki Ainamon Suomen Kuvalehdelle lähettämä teksti otsikolla Toivo Kuulan ampumistapaus.

— Suomen Kuvalehdelle 3.6.1960 lähetetty kirje otsikolla Arvoisa Toimitus. Nimimerkki Silminnäkijä - nyt 50 vuotias.

— A. Laitisen 29.8.1960 lähettämä kirje otsikolla Pianisti Sinikka Kuula, Helsinki.

\section{Lehdet}

HELSINGIN SANOMAT 30.10.2004. Ks. Niiniluoto 1978.

ILTA-SANOMAT 5.5.1958. Surmanlaukaus humussa ja sumussa. SUOMEN KUVALEHTI 30.4.1960. Ks. Sarkola 1960b.

\section{Internetsivut}

TOIVO KUULA - Wikipedia. < http://fi.wikipedia.org/wiki/Toivo_Kuula > [27.1.2005.]

TOIVO KUULA-SEURA RY. < http:/ /www.tks.pp.fi > [28.1.2005.]

\section{KiRJALlisuUs}

APO, SATU 1986: Ihmesadun rakenne. Juonien tyypit, pääjaksot ja benkilöasetelmat satakuntalaisessa kansansatuaineistossa. Suomalaisen Kirjallisuuden Seuran Toimituksia 446. Helsinki: Suomalaisen Kirjallisuuden Seura.

EEROLA, JARI \& EEROLA, JOUNI 1998: Henkilötappiot Suomen sisällissodassa 1918. Tammisaari: Tie Tammisaareen -toimikunta. 


\section{"KuULAA KALLOON"}

ELMGREN-HEINONEN, TUOMI 1953: Toivo Kuula. Toinen painos. [1938]

— 1983: Toivo Kuula. Kolmas uudistettu painos. Porvoo: WSOY. [1938]

FINGERROOS, OUTI 2004: Haudatut muistot. Rituaalisen kuoleman merkitykeset Kannaksen muistitiedossa. Suomalaisen Kirjallisuuden Seuran Toimituksia 985. Helsinki: Suomalaisen Kirjallisuuden Seura.

FORNÄS, JOHAN 1998: Kulttuuriteoria. Myöhäismodernin ulottuvunksia. Tampere: Vastapaino.

HAANPÄÄ, RIINA 2002: Pukkilan Jaska ja murha. - Elore 9(1) [online]. < http:/ /cc.joensuu.fi/ loristi/1_02/haa102.html > [30.1.2005.]

— Tarinat Pukkilan Jaskasta eteläpohjalaisuuden ilmentäjänä. - Sananjalka 45: 97-113.

HAAVIKKO, PAAVO 1978: Soitannollinen ilta Viïpurissa. Helsinki: Otava.

HABERMAS, JÜRGEN 1976: Tieto ja intressi. - Tuomela, Raimo \& Patoluoto, Ilkka (toim.), Yhteiskuntatieteiden filosofiset perusteet. Osa I. Helsinki: Gaudeamus.

KEARL, MICHAEL C. 1989: Endings. A Sociology of Death and Dying. New York: Oxford University Press.

KUULA, ALMA 1968: Virta venhettä vie. Päiväkirjat vuosilta 1901-1919. Porvoo: WSOY.

LAITINEN, KAI 1997: Suomen Kirjallisunden historia. Helsinki: Otava.

LAPPALAINEN, JUSSI T. 1981: Punakaartin sota 2. Punaisen Suomen historia 1918. Helsinki: Opetusministeriö, Punakaartin historiakomitea, Valtion painatuskeskus. NENOLA-KALLIO, AILI 1982: Studies in Ingrian Laments. Helsinki: Suomalainen tiedeakatemia.

NIINILUOTO, ILKKA 1980: Johdatus tieteenfilosofiaan. Käsitteen- ja teorianmuodostus. Helsinki: Otava.

NIINILUOTO, MARJA 1978: Pohjalainen pirunpolska. - Helsingin Sanomat 3.12.1978.

PAASIVIRTA, JUHANI 1957: Suomi vuonna 1918. Porvoo: WSOY.

PAAVOLAINEN, JAAKKO 1966: Poliittiset väkivaltaisundet Suomessa I. 'Punainen terrori'. Helsinki: Kustannusosakeyhtiö Tammi.

— 1967: Poliittiset väkivaltaisuudet Suomessa II. 'Valkoinen terrori'. Helsinki: Kustannusosakeyhtiö Tammi.

- 1971: Vankileirit Suomessa 1918. Helsinki: Kustannusosakeyhtiö Tammi.

PELTONEN, ULLA-MAIJA 1996: Punakapinan Muistot. Tutkimus työväen muistelukerronnan muotoutumisesta vuoden 1918 jälkeen. Suomalaisen Kirjallisuuden Seuran Toimituksia 657. Helsinki: Suomalaisen Kirjallisuuden Seura.

- 2003: Muistin paikat. Vuoden 1918 sisällissodan muistamisesta ja unobtamisesta. Suomalaisen Kirjallisuuden Seuran Toimituksia 894. Helsinki: Suomalaisen Kirjallisuuden Seura.

PENTIKÄINEN, JUHA 1969: The Dead without Status. - Temenos 4: 92-102.

- 1990: Suomalaisen lähtö. Kirjoituksia pobjoisesta kuolemakulttuurista. Suomalaisen Kirjallisuuden Seuran Toimituksia 530. Helsinki: Suomalaisen Kirjallisuuden Seura. 


\section{OUtI FingerRoOS}

PORTELLI, ALESSANDRO 2001: The Death of Luigi Trastulli and Other Stories. Form and Meaning of Oral History. New York: State University of New York Press. [1990]

— 2002: What Makes Oral History Different? - Perks, Robert \& Thomson, Alistair (eds.), The Oral History Reader. London: Routledge. [1998]

- 2003a: The Massacre at the Fosse Adreatine. History, Myth, Ritual and Symbol.

- Hodgkin, Katharine \& Radstone, Susannah (eds.), Contested Past. The Politics of Memory. London: Routledge.

— 2003b: The Order Has Been Carried Out. History, Memory, and Meaning of a Nazi Massacre in Rome. New York: Palgrave MacMillan.

RINTA-TASSI, OSMO 1986: Kansanvaltuuskunta punaisen Suomen hallituksena. Helsinki: Opetusministeriö, Punakaartin historiakomitea, Valtion painatuskeskus.

SARKOLA, RIKU 1960a: Toivo Kuulan kuolema. Vanha mysteeri selviämässä. - Suomen Kuvalebti 30.4.1960.

- 1960b: Toivo Kuulan matkanpää. Murhenäytelmä Viïpurissa 1918. Helsinki: K. F. Puromiehen kirjapaino.

SOIKKANEN, TIMO 1970: Luovutetun Karjalan työväenliikkeen historia. Helsinki: Kustannusosakeyhtiö Tammi.

TIMONEN, SENNI 2004: Minä, tila, tunne. Näkökulmia kalevalamittaiseen kansanlyrïkeaan. Suomalaisen Kirjallisuuden Seuran Toimituksia 963. Helsinki: Suomalaisen Kirjallisuuden Seura.

UKKONEN, TAINA 2000: Menneisyyden tulkinta kertomalla. Muistelupube oman historian ja kokemuskertomusten tuottamisprosessina. Suomalaisen Kirjallisuuden Seuran Toimituksia 797. Helsinki: Suomalaisen Kirjallisuuden Seura.

UPTON, ANTHONY F. 1981: Vallankumous Suomessa 1917-1918. II osa. Helsinki: Kirjayhtymä.

UTRIAINEN, TERHI 1999: Läsnä, riisuttu, pubdas. Uskontoantropologinen tutkimus naisista kuolevan vierellä. Suomalaisen Kirjallisuuden Seuran Toimituksia 751. Helsinki: Suomalaisen Kirjallisuuden Seura.

VILKUNA, KUSTAA 1949: Puukkojunkkarit, rahahäät ja heränneet. - Kotiseutu 1949(13): 131-135.

- 1969: Kansantaide ja perinnepolitiikea: Kansantaiteen seminaari Seinäjoella 10.6.-15.6.1968. Helsinki: Suomen Kulttuurirahasto.

WIKIPEDIA. Ks. Toivo Kuula.

YLIKANGAS, HEIKKI 1976: Punkkojunkkareitten esiinmarssi. Väkivaltarikollisuus Etelä-Pohjanmaalla 1790-1825. Helsinki: Otava.

\section{Outi Fingerroos (FT) on post doc -tutkimusta aloitteleva tutkijatohtori.}

